5. Повсеместное утверждение бесперспективности экстремизма, как в общественном, так и в личном плане (основной тезис: «экстремизм - это путь в никуда, на «дно», в нищету). Основа средств экстремистских организаций - доходы от «черного бизнеса». Это надо сделать достоянием гласности, проиллюстрировать - чего «добились» рядовые экстремисты.

Список литературы:

1. Бабаев М.М., Крутер М.С. Молодежная преступность / М.М. Бабаев, М.С. Крутер. - М.: Юристь, 2006. - 382 с.

2. Зубок Ю.А., Чупров В.И. Молодежный экстремизм: сущность и особенности проявления / Ю.А. Зубок, В.И. Чупров // Социс. - 2008.

3. Мартьянов В.С., Фишман Л.Г. Быть свободным или «бороться с экстремизмом / В.С. Мартьянов, Л.Г. Фишман // Новый мир. - 2008. № 11. - С. 132-152.

4. Милюкова И.А., Швец Л.П. Проявления ксенофобии в молодежной среде: региональные аспекты / И.А. Милюкова, Л.П. Швец // Молодежь и общество. - 2008. № 3. - С. 46-66.

5. Некоторые методические рекомендации по организации деятельности органов внутренних дел по противодействию экстремизма в молодежной среде / сост. О.В. Варакин. - Ставрополь, 2004. - 16 с.

6. Паин Э. Ксенофобия - экстремизм - терроризм / Э.Паин // Дружба Народов. - 2005. - №1.

7. Сальников Е.Ф. Экстремизм: фантоммедиакратии / Е.Ф. Сальников // Вестник МГУ. - Сер. 12. - Политические науки. - 2007. - 2007. - С. 52-56.

\title{
Сущность понятия «корпоративный клиент» в туризме
}

\author{
Печерица А.Е., учащийся, \\ НОУ «Бизнес-школа» «Деловая волна»", \\ 2. Санкт-Петербург \\ E-mail: helene8@yandex.ru
}

\section{Научный руководитель: к.с.н., доцент Печерица Е.В.}

Каждый год в мире совершается более 100 млн. поездок. И их географические дестинации характеризуется крайней неравномерностью. По статистике большинство поездок совершается со служебными целями и при этом пунктом назначения является Европа. Корпоративный туризм один из самых доходных и динамично развивающийся сегментов туристского рынка в мире. В мае 2003 году ЮНВТО насчитала свыше 100 млн. деловых поездок по всему миру, на которые приходилось приблизительно 30\% всех туристских прибытий в мире. Доходы от корпоративного туризма в 2009 году составили около 180 миллиард долларов, или приблизительно 40\% от всех поступлений международного туризма [1].

Работа с такой клиентурой — это прежде всего сотрудничество с организацией, в процессе которого нужно договариваться и наладить связи с целой группой лиц. Корпоративные продажи значительно отличаются от продаж розничных. 
Корпоративные продажи основываются на гораздо более сложных и трудоёмких, чем в розничных продажах, методах работы с клиентурой, также такие продажи подразумевают различные лояльные условия не только реализации услуг, товара, но и по дальнейшему сервисному обслуживанию. Данная клиентура имеет обычно установленный ряд эксклюзивных условий. Обычно рентабельность таких продаж ниже, чем в рознице, но при этом невысокая прибыль в некоторых случаях компенсируется крупными объёмами.

Истоки корпоративного туризма лежат в появлении делового туризма. Данный вид туризма является неотъемлемой частью корпоративного туризма, это основная база и большая поддержка для развития корпоративного туризма [2].

Деловой туризм - сравнительно новое явление. Началом можно считать 80-е гг. 20 столетия, на волне глобализации и связанной с ней научные, культурные, и деловые обмены, а также с увеличением доли населения среднего класса. В структуре деловых поездок, преобладают командировки предпринимателей, поездки на выставки и ярмарки, конгрессные туры, инсентив туры для работников компаний [3].

Европейский союз является первым в мире по числу прибытий и расходам на корпоративный туризм. Несмотря на данный факт, Европа потихоньку теряет лидирующие позиции в сегменте делового туризма. По темпам роста Европа отстает от других регионов мира, и этот разрыв постоянно увеличивается [4].

В 90-х гг 20 века, когда в условиях экономического кризиса, большинство фирм перешли к строгой экономии финансовых средств, компании начали сокращать количество командировок своих сотрудников, объединяли несколько деловых поездок в одну, вводили новые системы связи, которые служили для решения большинства вопросов, не выезжая из страны. Компании бронировали дешевые гостиницы, а также покупали авиабилеты со скидкой. В отличие от европейских фирм, американские и азиатские фирмы продолжали и продолжают наращивать объемы финансирования в деловые поездки для своих сотрудников. Несмотря на мировой кризис, они увеличили расходы на корпоративные поездки, но при этом начали экономить на организации отдыха и развлечений для менеджеров компании.

Корпоративный туризм является следствием появления корпоративной культуры. Топ менеджеры организаций понимают, что для достижения коммерческих целей и укрепления позиций организаций на рынке важны не только деловые контакты и обучение персонала фирмы, а также сплоченная команда и благоприятный климат в коллективе.

Корпоративный туризм состоит из множества различных элементов. В корпоративной поездке есть несколько вариантов для ее проведения. Отдых можно совместить с семинаром или с деловыми встречами, а можно совершить с коллегами по работе путешествие по стране или за ее пределами [5].

Корпоративные поездки, которые носят деловой характер - это насыщенная и спланированная программа встреч и мероприятий. Туристским организациям без упорной работы с клиентом, не обойтись без понимания профессиональной деятельности клиента и четкого видения именно деловых целей. Такие мероприятия организуются, с полной культурной и экскурсионной программой. В данную программу входит проживание в отеле, завтраки, трансферы, оформление визы. За дополнительную плату, клиентам предоставляются такие услуги как: аккредитация на выставку или входные билеты, услуги переводчика или гида. Клиентам предоставляют специальные тарифы на перелеты в бизнес классе, организация V.I.P. обслуживания в 
аэропортах и т.п.

К основным целям совершения корпоративных поездок относятся:

- $\quad$ проведение встреч и переговоров с партнёрами из других фирм;

- $\quad$ проведение совещаний с менеджментом и коллегами, представителями дочерних структур и филиалов;

- проверка работы представительств и филиалов;

- у установление и налаживание деловых контактов;

- п посещение профессиональных мероприятий (конференций, выставок и

т.д.);

- $\quad$ обучение сотрудников организации;

- $\quad$ обращение в государственные органы разных стран, с целью получения сертификатов, разрешений, лицензий и т.д.

Есть несколько видов корпоративного туризма (Таблица 1).

Существуют корпоративные и некорпоративные поездки. Некорпоративным и корпоративным поездкам присущ ряд особенностей.

К особенностям корпоративных поездок относятся;

- $\quad$ фирмы обращаются за помощью компаний, профессионалов, которые занимаются организацией деловых встреч (турфирм);

- $\quad$ корпоративные встречи проводят для небольшого числа сотрудников компании (в среднем на 15 человек).

Таблица 1

Виды корпоративного туризма

\begin{tabular}{|l|l|}
\hline $\begin{array}{l}\text { Конгрессные } \\
\text { Поездки }\end{array}$ & $\begin{array}{l}\text { Это когда люди посещают различные выставки и презентаций по всему } \\
\text { миру. Сотрудники компаний с разных стран приезжают на конференции и } \\
\text { семинары, чтобы получить новую информацию в той области, где они } \\
\text { работают [6] }\end{array}$ \\
$\begin{array}{l}\text { Программы поощрения для лучших сотрудников компании за отличную } \\
\text { работу, по усмотрению начальство предприятия. Можно также поощрить } \\
\text { и денежными вознаграждениями, но как показывает практика во всем } \\
\text { мире, премирование туристической поездкой, даёт больший стимул для } \\
\text { отличной работы сотрудников. У сотрудников появляется стремление к } \\
\text { успехам в работе в дальнейшем. Но данный вид туризма обходится } \\
\text { организациям очень дорого, поэтому позволить их могут только не все } \\
\text { [7] }\end{array}$ \\
\hline $\begin{array}{l}\text { Большинство руководителей фирм постоянно стараются улучшить } \\
\text { квалификацию работников, и для этого сотрудников компании } \\
\text { отправляют на стажировки в другие города или страны. Обычно } \\
\text { стажировки за рубежом не оплачиваются, поэтому фирма оплачивает } \\
\text { проживание сотрудников. Тем самым предполагая, что средства, } \\
\text { потраченные на сотрудника, впоследствии должны окупиться. } \\
\text { Специалисты данной компании сами заинтересованы в получении новых } \\
\text { знаний, которые в дальнейшем помогут им в работе и в продвижении по } \\
\text { карьерной лестнице [7] }\end{array}$ \\
\hline
\end{tabular}

К особенностям некорпоративного поездок относятся: 
- $\quad$ как правило, такие мероприятии проводятся для большого количества сотрудников организации (150-200 человек);

- большинство некорпоративных поездок проводится осенью и весной это время, когда отмечается значительный спад туристской активности (из этого следует, что развитие данного вида туризма способствует сглаживанию сезонных колебаний);

- $\quad$ некорпоративные путешествии имеют ярко выраженную специализацию, большинство из них связано с областью медицины, а также со сферами технологий и промышленности;

- $\quad$ в большинстве случаев в процессе организации некорпоративных мероприятий всегда присутствует организатор встреч со стороны.

Расходы компаний на корпоративный и некорпоративный деловой туризм примерно одинаковы: 47 \% средств используются для покупки авиабилетов, 24\% номер в отеле, 13 \% - на питание, 7 \% -транспортные расходы и 9 \% занимают прочие расходы. (Рисунок 1) [8].

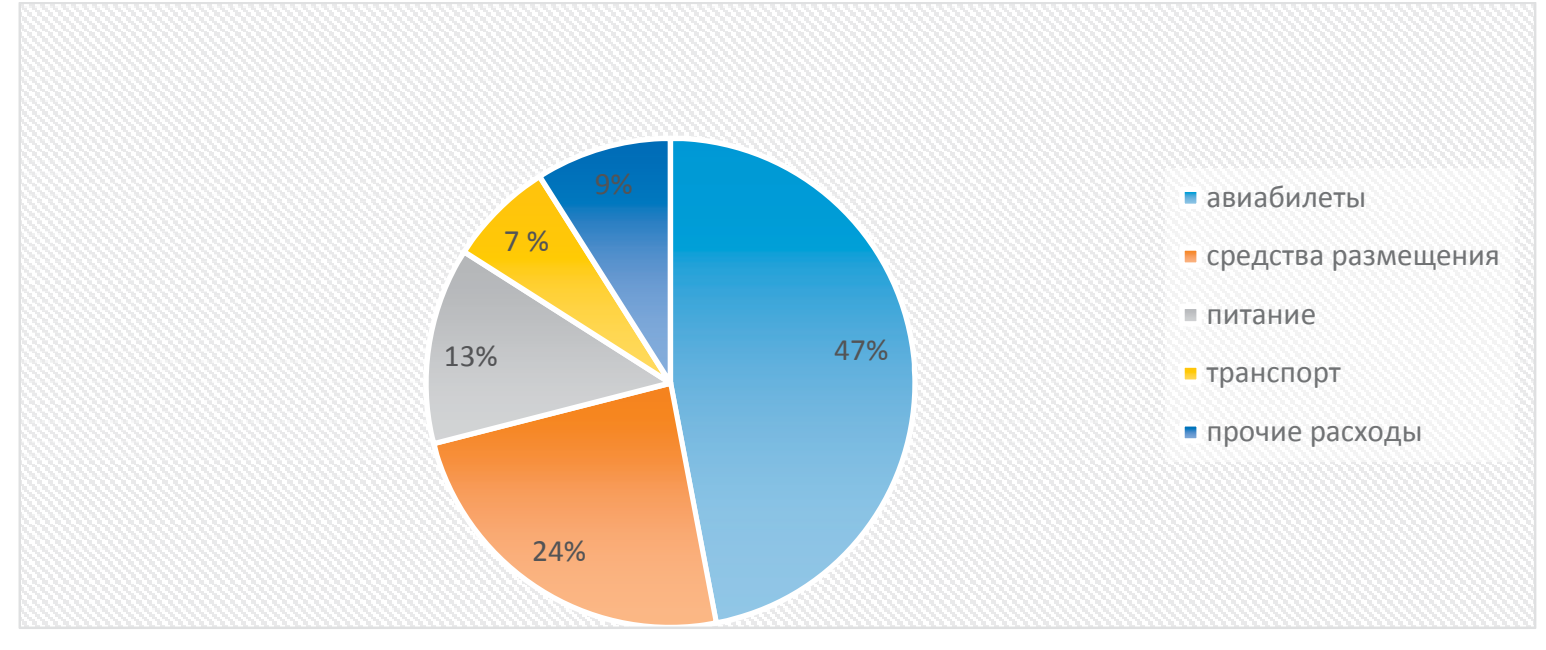

Рис. 1. Структура расходов корпоративных туристов

С каждым годом деловые, культурные и научные связи между регионами и странами становятся все более интенсивными. Деловой туризм играет в этом важную роль. Развитие отечественной экономики и интеграция ее в мировой рынок тоже немыслимы без развития сферы делового туризма.

\section{Список литературы:}

1. Caldito L.A., Dimanche F., Mazina A., Fedulin A., Vetitnev A., Apukhtin A., Kruzhkov D., Kurbanov E., Pecheritsa E., Sakharchuk E., Sharafanova E., Romanova G., Alexanyanc G., Tatarskikh Iu., Belosluttseva L., Smit N., Kryukova O., Vapnyarskaya O., Ilkevich S., Kharitonova T. et al. TOURISM IN RUSSIA. TEMPUS Project "NETOUR: Network for Excellence in Tourism through Organization and Universities in Russia" / Project Co-funded by the European Union. Spain, 2015. 28 p.

2. Печерица Е.В. Управление туристской отраслью на федеральном, региональном и муниципальном уровнях. Международный научно-исследовательский журнал. 2014. № 1-3 (20). С. 55-56. 
3. Рубан Д.А. Инновационный менеджмент в туризме: направления и управленческие действия. Вестник УрФУ. Серия: Экономика и управление. 2015. Т. 14. № 1. С. 114-126.

4. Печерица Е.В. Позиционирование предприятий индустрии гостеприимства в условиях конкуренции. монография / Е. В. Печерица; М-во образования и науки Российской Федерации, Федеральное агентство по образованию, Санкт-Петербургский гос. ун-т сервиса и экономики. Санкт-Петербург, 2010. 163 с.

5. Профессионально-деловой туризм.- URL: http: //aa-tour.ru/tour-types/business/

6. Интенсив-туры. - URL: http: //www.vivat-is.ru/yet_tour

7. Печерица Е.В., Шевченко М.И. Инновационные технологии в гостиничном бизнесе. монография / Санкт-Петербургский государственный университет сервиса и экономики. Санкт-Петербург, 2013. 135 с.

8. Гомилевская Г.А. Региональные модели организации внутреннего туризма. Сайт цифровых учебно-методических материалов ВГУЭС.- URL: http://abc.vvsu.ru/Books/u_regmod/page0004.asp

\section{Правовое регулирование организации и деятельности Государственной инспекции труда (на материалах Новосибирской области)}

Полупанова А.А., студентка, Сибирский институт управления - филиал РАНХиГС, 2. Новосибирск E-mail: polupanova9519@mail.ru

Научный руководитель : к.ю.н, доцент Сигарев А.В.

Аннотация: Анализируются вопросы государственного контроля и надзора за охраной труда и соблюдением трудового законодательства.

Ключевые слова: трудовые отношения, трудовое законодательство, инспекция труда.

Вопросы защиты прав и законных интересов граждан занимают одно из важнейших мест в правовой системе Российской Федерации. Так, Конституция Российской Федерации в ст. 45 гарантирует государственную защиту прав и свобод человека и гражданина, в том числе и трудовых прав работников [1].

Трудовой кодекс Российской Федерации является основой всей законодательной базы в области трудовых отношений. Последняя принятая версия датируется 30 декабря 2001 г. с редакцией от 30 декабря 2015 г. По состоянию на 31 декабря 2015 г.приказами Минтруда России утверждено 804 профессиональных стандарта [3]. Государственными инспекциями труда на территории РФ в 2015 г. было организовано и проведено 138,5 тыс. проверок по вопросам соблюдения законодательства о труде, что на 4,4\% больше, чем в 2014 г. В целом, можно отметить, что тенденция увеличения ежегодного числа проверок началась в 2014г., причиной чего могла стать сложившаяся в мире непростая политическая и экономическая ситуация. Согласно данным Росстата численность экономически активного населения в среднем за 2015 год составила 76,6 млн. человек, в их числе 72,3 млн. человек были заняты экономической деятельностью, 